\title{
組織球性壊死性リンパ節炎
}

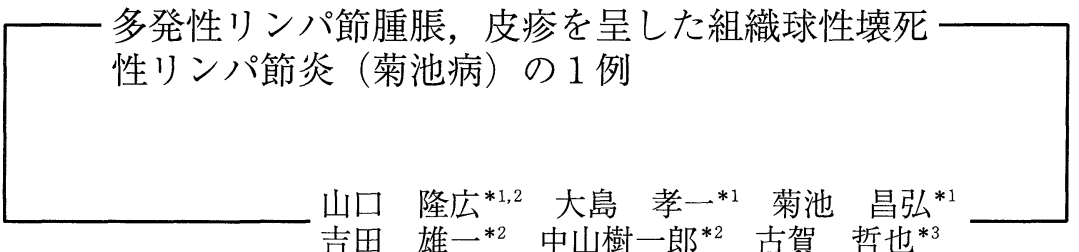

吉田 雄一 ${ }^{* 2}$ 中山樹一郎*2 古賀 哲也*3

\section{A case of histiocytic necrotizing lymphadenitis with eruption and systemic lymph node \\ Takahiro YAMAGUCHI ${ }^{* 1,2}$, Koichi OHSHIMA ${ }^{* 1}$, Masahiro KIKUCHI ${ }^{* 1}$, Yuichi YOSHIDA *2, Juichiro NAKAYAMA *2, Tetsuya KOGA *3 \\ *1 Department of Pathology, School of Medicine, Fukuoka University \\ *2 Department of Dermatology, School of Medicine, Fukuoka University \\ *3 Department of Dermatology, Graduate School of Medical Sciences, Kyushu University}

A 14-year-old girl was admitted to the hospital due to systemic lymph node swelling with tenderness, fever, erythematous skin lesions and bicytopenia. Her condition was diagnosed as histiocytic necrotizing lymphadenitis (HNL) determined by a biopsy of her enlarged cervical lymph node. The biopsy of the skin rash revealed infiltrates of $\mathrm{T}$ lymphocytes, histiocytes with numerous apoptotic cells the same as the nodal lesion, and was considered to be the cutaneous lesion of HNL. [Skin Cancer (Japan) 2003 ; 18: 13-16]

Key words: Histiocytic necrotizing lymphadenitis, Eruption, Cutaneous histology

はじめに

組織球性壊死性リンパ節炎 histiocytic necrotizing lymphadenitis (以下 HNL) は，病 理組織学的に, 壊死, 核崩壊産物, 組織球およ び幼若化リンパ球の浸潤を特徴とし, 若い成人 女性の頸部リンパ節を冒す予後良好な炎症性疾 患である。今回我々は, 多発性リンパ節腫脹, 全身の浸潤性紅斑を呈した女児の HNL を経験

*1 福岡大学医学部病理学教室

*2 福岡大学医学部皮膚科学教室

*3 九州大学医学部皮膚科学教室
し，その皮膚病変について検討したので文献的 考察を加え報告する。

\section{症例}

患 者: 14 歳, 女性

既往歴, 家族歴：特記事項なし。

現病歴: 平成 13 年 9 月末より 39 度台の発熱 を認めた。10月中旬に近医皮虐科を受診し汎血 球減少, 軽度の肝機能障害と炎症反応に加え, 脾腫，頸部，鎖骨上，腋窩のリンパ節腫脹を認 めた。精査, 加療目的で某大学病院小児科入院 となった。入院後の CT で肺門部, 腹部大動脈 
周囲リンパ節腫脹を認めた。入院時, 顔面に紅 斑を認め，入院後躯幹，下肢に皮疹が拡大し皮 膚科受診となった。

初診時現症：両大腿, 膝部に軽度の瘙痒を伴 う浸潤性紅斑を認めるとともに（図1）, 㚘部, 背部に淡い紅斑を認めた。両頸部，鎖骨上窩， 腋窩に径 $1 \mathrm{~cm}$ 程度の複数のリンパ節腫脹を認 めるとともに脾腫も認めた。

臨床検查所見 : WBC : 2030/ $\mu l$ (neutro : 78.0 $\%$, lymph: $14.5 \%$, mono: $4.5 \%$, eosino: $4.5 \%$, Aty lymph :2.0\%), $\mathrm{RBC}: 4.1 \times 10^{6} / \mu l, \mathrm{Hb}: 8.5$ $\mathrm{g} / \mathrm{d} l, \quad \mathrm{Plt}: 147 \times 10^{3} / \mu l, \quad \mathrm{TP}: 6.8 \mathrm{~g} / \mathrm{d} l, \quad \mathrm{Alb}: 3.2$

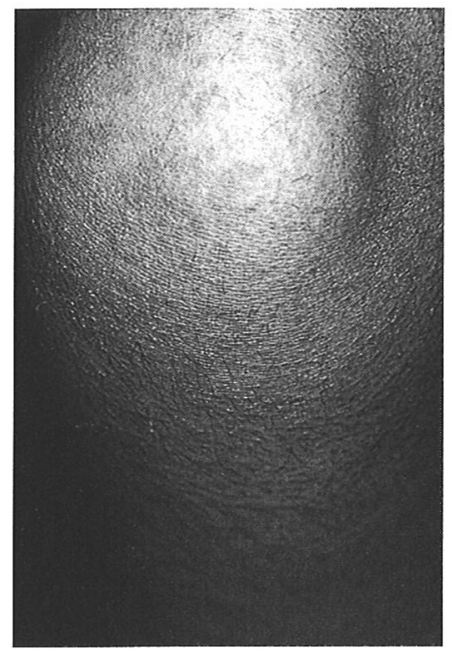

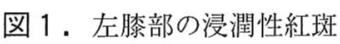

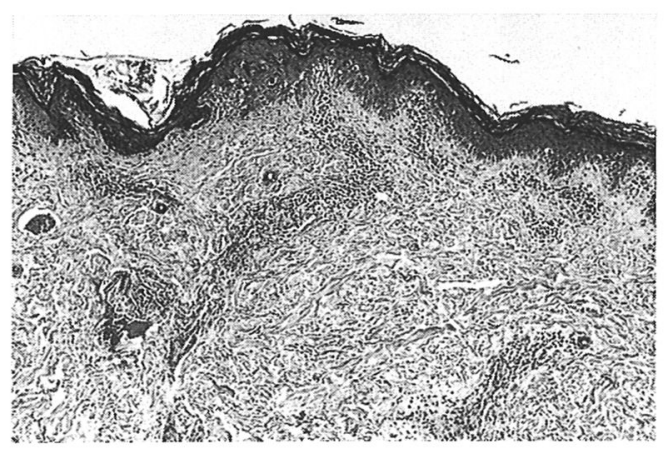

図 3A．左膝部紅斑の病理組織像（H.E. 染色） 真皮上層血管周囲性にリンパ球，組織球の浸 潤。真皮には壊死性の変形を認める $\mathrm{g} / \mathrm{d} l, \quad$ BUN $: 8 \mathrm{mg} / \mathrm{d} l$, Crea $: 0.57 \mathrm{mg} / \mathrm{d} l$, AST : $68 \mathrm{U} / \mathrm{L}$, ALT: $32 \mathrm{U} / \mathrm{L}, \mathrm{LDH}: 663 \mathrm{U} / \mathrm{L}$, ALP : 262 U/L, $\gamma$-GTP : $29 \mathrm{U} / \mathrm{L}, \mathrm{ChE}: 106 \mathrm{U} / \mathrm{L}$, $\mathrm{Na}: 138 \mathrm{mmol} / l, \mathrm{~K}: 4.2 \mathrm{mmol} / \mathrm{l}, \mathrm{Cl}: 102 \mathrm{mmol} / l$, CRP : $0.28 \mathrm{mg} / \mathrm{d} l$, 抗核抗体 $(-)$, 抗 DNA 抗体 (-), RAHA(-), LE-test(-), C3: $120 \mathrm{mg} / \mathrm{d} l, C 4$ : $22 \mathrm{mg} / \mathrm{d} l, C H 50: 48 \mathrm{U} / \mathrm{m} l, E B V$ 抗体価：既感 染パターン。

病理組織所見：頸部リンパ節；拡大した傍皮 質部に, 組織球と大型化したリンパ球が巣状に浸 潤するとともに核崩壊産物を多数認める(図 2)。

皮膚 ; 膝部の浸潤性紅斑を生検した。真皮上 層血管周囲性に組織球とリンパ球の浸潤を認 め, 少数ながら核崩壊産物も認める(図 $3 A, B$ )。

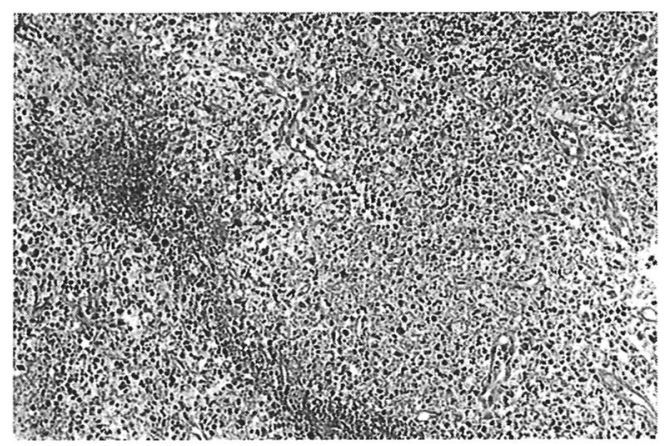

図 2. 左頸部リンパ節生検組織像 (H.E. 染色) 拡大した傍皮質に大型，芽球化したリンパ 球, 組織球および多数の核崩壊産物を認める。 壊死性変形を伴う

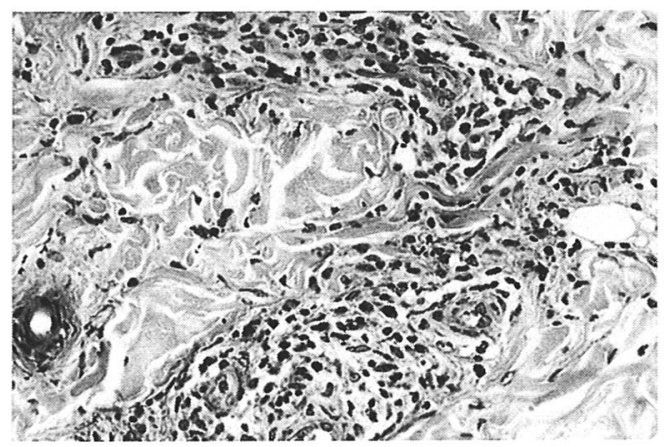

図 3B. 真皮上層血管周囲性にリンパ球, 組織球およ び核崩壞産物を認める 


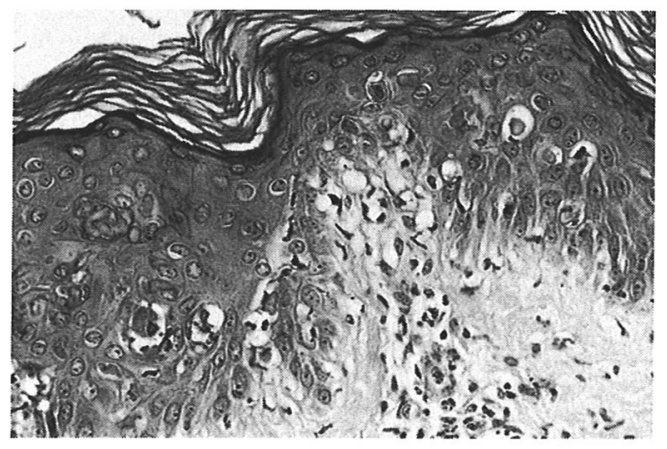

図3C，表皮にはCivatte bodyを認め，軽度の exocytosis を呈する

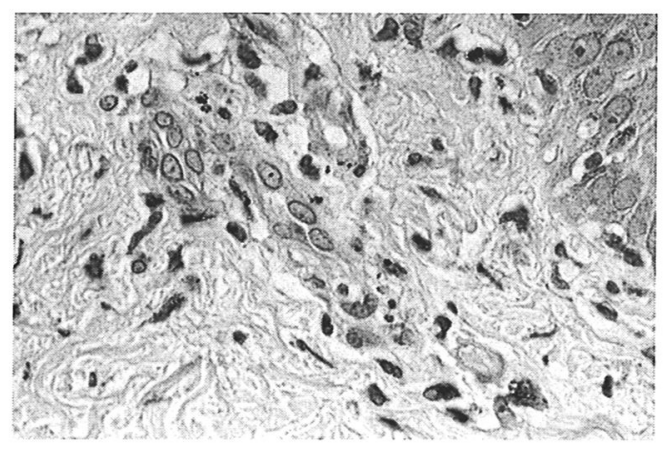

図 5.Ki-MIP 陽性の形質細胞様単球を認める

表皮には多数の Civatte body を認め, 壊死性变 化を呈した（図 3C）。免疫染色では浸潤組織球 はCD68 陽性であった（図 4)。リンパ球は CD45RO 陽性，そのうち少数が CD8 陽性。CD4 陽性細胞の一部は Ki-M1p 陽性（図 5 )。

治療と経過：臨床的, 病理組織学的に HNL と 診断し，プレドニゾロン $30 \mathrm{mg} /$ day の内服を開 始し, 速やかに全身症状, リンパ節腫脹, 皮疹 は改善した。減量, 中止後も症状の再燃は認め ていない。

\section{考察}

組織球性壊死性リンパ節炎（HNL）は，主に 若い成人女性の頸部リンパ節を冒す予後良好な 炎症性疾患で，1972 年に菊池ら ${ }^{11}$ が初めて報告 した。このため菊池病とも呼ばれる。臨床的な

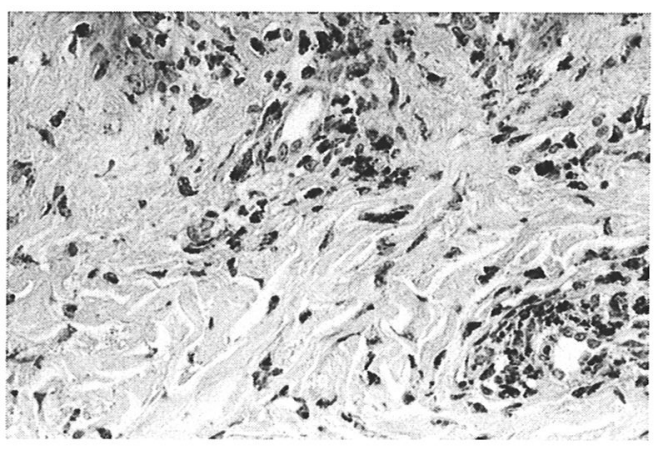

図 4.免疫組織染色にて組織球は CD68 陽性

特徴としては, 10 30 歳代に発症し, 男女比は 1：2であり，若年女性に多い傾向がある。 $80 \%$ 以上の症例で圧痛を伴う頸部リンパ節腫脹で発 症するが，約 5\% は全身のリンパ節腫大を認め る。本症例の様に深部リンパ節腫脹を伴うもの は極めて稀とされる ${ }^{2)}$ 。また 38 度以上の抗生剤 不応性の発熱をしばしば伴い (38\%), 風疹様, 中毒疹様，播種状紅斑様，多型紅斑様などの皮 疹を伴うことがある（20\%） 3) 6)。自験例は， 多型紅斑様ともいうべき所見であった。臨床検 査所見上の特徵としては， $4000 / \mathrm{mm}^{3}$ 以下の一 過性白血球減少 (56\%), 未梢血中の 1 2\%の異 型リンパ球の出現 $(23 \%), \mathrm{LDH}$ の上昇も時にみ られ特に壊死病変の目立つ症例ではその頻度が 高く上昇も著しい。リンパ節の病理組織所見が 確定診断となる。大型化したリンパ球抢よび組 織球が，腫大した傍皮質部に増殖し，病変中に は多くの核崩壊産物が存在し，一部は組織球に 頜食されている。免疫組織学的には浸潤組織球 はリゾチーム, CD68 陽性である。大型化細胞の 大多数は CD4， CD8 陽性で， CD4 陽性細胞の 一部は CD3 陽性であるが, 他の T 細胞マーカー は陰性である。そしてこの CD4 陽性の T 細胞 マーカー陰性細胞は Ki-Mlp に陽性であること から, 形質細胞様単球の所見に一致する ${ }^{71}$ 。CD8 陽性細胞は CD3 陽性であり, さらに $\alpha \beta \mathrm{TCR}$ に反応寸る。また増殖抗原が認められるものも 主として CD8 陽性 T 細胞である ${ }^{81}$ 。以上より病 
変は，増殖する $\mathrm{CD} 8$ 陽性 T 細胞とともに CD4 陽性のいわゆる形質細胞様単球, 組織球ならび にCD4 陽性 T細胞で構成されている ${ }^{2)}$ 。全体に $\mathrm{CD} 8$ 細胞が CD4 細胞に比較し優位である。壊死 は二次性の変化で，発症からの経過が長く，発 熱，疼痛の著明なもののリンパ節で目立つこと が多い。

皮膚病変の組織像は，真皮血管周囲性のリン パ球主体の炎症細胞浸潤を呈する場合と，血管 周囲性に組織球，大型のリンパ球，核崩壊産物

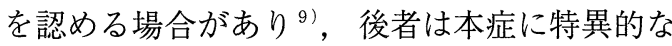
組織像である。自験例は後者の組織像を呈して おり，本症の皮膚病变と考えて差し支えないと 思われるが，表皮の壊死性変化は非典型的で あった。また皮膚の免疫組織所見で，浸潤リン パ球は CD45RO 陽性でその一部は CD8 または CD4 が陽性であった。CD3 も一部は陽性であっ た。また CD4のみ陽性で他の T 細胞系マーカー が陰性のものは Ki-Mlp 陽性でいわゆる形質細 胞様単球の所見に一致するものであった。

治療はステロイドの投与が著効するが，無治 療でも1〜4 カ月程度で自然治癒する。

鑑別すべき疾患としては，まず悪性リンパ腫 があげられる。本症は病変部に核分裂像が多数 みられることから，悪性リンパ腫と誤って診断 されることがある。特に自験例は深部リンパ節 を含む全身性の多発性リンパ節腫脹を認めてお り，リンパ腫との鑑別が必要であった。反応性 病変としては限局性単球様 B 細胞増殖がある。 これはしばしばウイルス感染でみられる。また トキソプラズマ性リンパ節炎もあげられるが, これは類上皮細胞小集合巣がみられる。壊死病 変が強いときは結核性リンパ節炎，猫ひっかき 病，SLEが鑑別に挙げられる。SLEではときに 壊死巣を取り巻いて大型化リンパ球の集合をみ ることがあり鑑別困難であるが，血液検査所見
により鑑別しうる。発症因子はウイルス感染が 疑われているが現在のところ Epstein-Barr virus, parainfluenza-III, human herpesvirus-6 などの検索がなされているが，特異的なものは 見出されていない。しかし, human herpesvirus6 に関しては，病変部に高率に HHV-6 に単ク ローン性抗体陽性細胞を認めることなどから， 病変の発生, 進展に関与している可能性が考慮 されている ${ }^{10)}$ 。

\section{文献}

1）菊池昌弘：特異な組織像を呈するリンパ節炎につ いて，日血会誌，35：379-380, 1972

2）菊池昌弘，住吉慶明：組織球性壊死性リンパ節炎 (菊池・藤本病)。病理と臨床， $12: 375-378,1994$

3）矢幡 敬, 吉利優子, 帯刀英二：組織球性壊死性 リンパ節炎の 1 例。皮膚診療，9:953-956, 1987

4) 戸井洋一郎, 野原 望, 立花英夫: 成人スチル病 との鑑別が問題となった組織球性壊死性リンパ節 炎の 1 例．皮膚臨床，36:131-135, 1994

5）高橋典大, 星野 稔, 馬場 徹, 他: 組織球性壊 死性リンパ節炎。西日皮膚，51:227-231, 1989

6）松村文子, 清水昭彦, 渋江賢一, 他：組織球性壤 死性リンパ節炎（菊池病）の 1 例．皮虐臨床，40 :817-820, 1998

7) Hansmann ML, Kikuchi M, Wacker HH, et al : Immunohistochemical monitoring of plasmacytoid cells in lymph node sections of KikuchiFujimoto disease by a new pan-macrophage antibody Ki-M1P. Human pathol 23 : 676-680, 1992

8) Ohshima K, Kikuchi M, Sumiyoshi Y, et al : Proliferating cells in histiocytic necrotizing lymphadenitis. Virchows Arch B, 61: 97-100, 1992

9) Sumiyoshi Y, Kikuchi M, Takeshita M, et al : Immunohistological study of skin involvement in Kikuchi's disease. Virchows Arch B, 62 : 263-269, 1992

10）住吉慶明，菊池昌弘：組織球性壊死性リンパ節炎 (菊池病) と HHV-6. 血液・腫瘍科, 27:67-75, 1993 